\title{
PO STOPÁCH HUDOBNOESTETICKÉHO MYSLENIA NA SLOVENSKU V 15.-17. STOROČÍ SO ZAMERANIIM NA ÚZEMIE SPIŠSKEJ A ŠARIŠSKEJ STOLICE
}

\author{
SLÁVKA KOPČÁKOVÁ
}

Inštitút estetiky a umeleckej kultury, Filozofická fakulta, Prešovská univerzita

slavka.kopcakova@unipo.sk

\begin{abstract}
Following the Formulation of Musical-and-Aesthetical Thinking is Slovakia between the 15th and 17th centuries with the Focus on the Area of Spiš and Šariš

Regionally aimed research into musical-and-aesthetical thinking accounts for only a small part of explored scientific issues that require broader philosophical, art-theoretical as well as linguistic erudition. Summarizing of relevant sources that have been discovered to date provides scope for making evaluations and outlining some possible research strategies. A very important source for our knowledge is musical-and-theoretical treatises that (in certain passages) sporadically go into areas considering music influence on the listener, perception mechanisms as well as their impact on the sense of paideia taken into account by the then scholars. Apart from rarely occurring treatises, analysis of other texts, e.g. literature artworks, linguistics works with etymological or dictionary focus, reflections of composers etc. leads us to new knowledge too.
\end{abstract}

Keywords: music; theory of music; education; musical culture

\section{Prehistória - po stopách estetického myslenia o hudbe na Slovensku}

Dejiny estetického myslenia sú súčastou kultúrnej pamäti ludstva, estetické myslenie zhmotňuje a zaznamenáva (vo väčšine prípadov) verbalizované výsledky uvažovania nad prežívaním ludského života a poznaním cez estetické vnímanie a cez kognitívne procesy za účasti emocionálnej výbavy subjektu $v$ ich prepojenosti. Ich výsledkom je u aktívneho subjektu vnímanie zmyslu, nahliadanie, duchovné spracovanie, reflexia a hodnotenie. Dejiny estetického myslenia začínajú rekognoskáciou terénu vo filozofických systémoch staroveku a antiky, ako aj pri prvých zachytených reflexiách týkajúcich sa umenia. Antická estetika reprezentovaná Platónom, Aristotelom a ich nasledovníkmi je však „estetikou" iba v prenesenom zmysle slova, resp. estetikou dobovo nepomenovanou, napriek tomu je zahŕňaná do dejín estetického myslenia ako jej počiatočná fáza, resp. legitímna prehistória či aj inšpiračný zdroj pre všetky dalšie estetické školy, smery či línie. Tak ako dejiny estetickej reflexie abstrahujeme pred rokom 1750-1758 (Baumgartenova Aesthetica) najmä z dobových filozofických systémov a ich pojednaní (traktujúcich aj otázky umenia a estetického osvojovania si umenia), podobne existenciu hudobnoestetických úvah môžeme abstrahovat v skorších obdobiach temer výlučne $\mathrm{z}$ historických hudobnoteoretických traktátov, prípadne zo vcelku nemnohých, ale o to vzácnejších, autentických výpovedí hudobných tvorcov doby či zriedkavo aj z literárnych prameňov. 
Z metodologického hladiska sme pojem „prehistória“ pre účely tejto štúdie použili presne $\mathrm{v}$ duchu jeho etymologického chápania ako prvé obdobie niečoho, resp. absolútne poznatelné či dokumentovatel'né začiatky niečoho. Prehistóriou hudobnoestetického myslenia označujeme prvopočiatky myslenia o hudbe, resp. prvé písomné pamiatky v oblasti hudobnoteoretickej spisby. Pri výskume najstarších období je možné opierat sa o traktáty, ktoré vznikli na území Slovenska, teda a priori vylúčime také (je ich nepomerne viac), ktoré ako odpisy, či dokonca ako vzácne tlače európskych autorov patria do depozitov historických fondov našich knižníc, múzeí či archívov. ${ }^{1}$ Metódou našej práce je sumarizácia doposial objavených a relevantných prameňov a ich selekcia, ako aj analýza informácií z najstarších nájdených traktátov takého druhu u nás, prípadne z iných textov: napríklad pôvodné filozofické traktáty a sekundárna literatúra o nich, literatúra a jazykovedné práce, kanonické vizitácie a pod. Avšak výskyt nami favorizovaných hladaných údajov v nich zvyčajne býva skôr náhodný, sporadický, nesystematický, často s rozkolísaným významovým kontextom a výpovednou hodnotou.

Prehistóriou (pojmovou adaptáciou zvolenou ako vhodnú zastrešujúcu ideu pre pokus o náčrt problematiky) sme pre potreby časového vymedzenia našich úvah nazvali obdobie od druhej polovice 15. storočia až po poslednú tretinu 19. storočia, aj ked' naša štúdia nepojednáva o celom tomto období. ${ }^{2}$ Až v 19. storočí sa u nás objavilo autentické hudobnoestetické myslenie reprezentované náhladmi Jána Levoslava Bellu v jeho tažiskovej práci Myšlienky o vývine národnej hudby a slovenského spevu (1873). ${ }^{3}$ To, čo prišlo po rokoch Bellovej mladosti a jeho aktivít na poli umeleckej tvorby a jej vlastnej reflexie teda budovanie slovenskej hudobnej kultúry po roku 1918 v jej napojení na výdobytky českej hudobnej vedy a estetiky, s následným formulovaním programu estetiky slovenskej hudobnej moderny Ivanom Ballom v 30. rokoch a napokon so vznikom teoretických prác zakladajúcich u nás tradíciu hudobnej estetiky ako vedeckej disciplíny z pera Jozefa Kresánka a Ota Frenczyho v 40. rokoch 20. storočia - to už je reálna novodobá história. ${ }^{4}$

Hladat počiatočné momenty zrodu hudobnoteroetickej spisby s črtami estetického myslenia na Slovensku, značí mat k dispozícii zachované pramenné materiály - predovšetkým traktáty o teórii hudby v podobe náuky pre potreby praxe (musica practica), o podstate hudby a jej začlenení do dobových teoretických filozofických a vedných systémov (musica theoretica), o pravidlách jej komponovania (musica poetica), prípadne o jej vyučovaní. $\mathrm{V}$ tejto štúdii vychádzame jednako $\mathrm{z}$ vlastného pramenného bádania, jednako z pramenného bádania iných muzikológov, v prípade najstarších prameňov využívame

1 Berieme teda do úvahy iba na našom území vzniknuté pramene, i ked’ sú vo väčšine prípadov poplatné tým európskym, dokonca sa často približujú svojou povahou typologicky kompilátu alebo aj odpisu (s prispôsobením predlohy pre potreby učebnej praxe alebo s poznámkami odpisujúceho autora). To bola totiž bežná a legitímna „publikačná prax“ v minulých stáročiach. Sensu stricto iba domáce pramene od domácich autorov možno považovat za relevantné pri hladaní nitiek hudobnoteoretického myslenia na našom území, vedúcich k estetických názorom na hudbu, jej pôsobenie a osvojovanie.

2 V našej štúdii spracúvame ako pilotné pojednanie výsek problematiky výberom z traktátov 15.-17. storočia.

3 J. L. Bella, Myšlienky o vývine národnej hudby a slovenského spevu, Hudobnovedný zborník SAV, roč. 1, 1953, s. 20-48, SAV, Bratislava. Hudobnoestetické náhlady Jána Levoslava Bellu sú predmetom analýz viacerých autorov ako J. Lengová, S. Kopčáková, pozri bližšie čast Literatúra.

4 Pozri bližšie S. Kopčáková, Vývoj hudobnoestetického myslenia na Slovensku v 20. storočí, FF PU, Prešov 2013. 
aj interpretačnú literatúru iných autorov z posledných dvoch desatročí. ${ }^{5}$ Pre vstup do problematiky sme zvolili príklady z regiónu východného Slovenska ako najsevernejšej časti bývalého Uhorského královstva nie z dôvodu, že by v iných častiach nášho územia na úsvite novoveku nebolo funkčné školstvo či nepôsobili umenie reflektujúci učenci. Dôvodom je prirodzená bádatel'ská orientácia autorky práce a snaha regionálne ukotvit’ vedecké aktivity a zintenzívnit poznanie regionálnej pramennej základne.

\section{Estetika hudby v 15. storočí na príklade najstaršieho hudobnoteoretického traktátu na Slovensku}

Podla doterajších výskumov na území východného Slovenska nachádzame hudobnoteoretické traktáty obsahujúce aj určité estetické náhlady na hudbu a jej zmyslové účinky už na konci 15. storočia, ich pôvod je v školskom prostredí latinských škôl, kde vznikali spravidla na didaktické účely. Na tomto mieste sa zmienime iba o jedinom prameni tohto druhu, ktorý máme k dispozícii a ktorý je ešte stále predmetom výskumov z hladiska spresňovania jeho pôvodu, autorstva a komparácie s dobovými európskymi poznatkami z hudobnej teórie. V druhej polovici 20. storočia bol v čase zintenzívnenia muzikologických výskumov na východnom Slovensku objavený tzv. Levočský hudobnoteoretický traktát (resp. jeho fragment) ${ }^{6} \mathrm{z}$ roku 1477. Jeho korene sú pravdepodobne na Spiši a je dosial' najstarším objaveným primárnym dokumentom hudobnoteoretického myslenia, ktorý vznikol u nás. ${ }^{7}$ Napísaný a používaný bol pravdepodobne pre každodennú prax vyučovania hudby na latinskej stredovekej škole. Traktáty tohto druhu sú vždy prácami autorsko-kompilačného charakteru poplatné svojim vzorom, ktoré ich autori spoznali počas štúdií na európskych univerzitách.

Univerzálnou tézou výchovy počas celého stredoveku na všetkých druhoch a stupňoch škôl bolo teoretické a praktické ovládanie hudby „Ars musica“: „Slovo a spev, písmo a hudba ostávajú však i nad’alej rozhodujúcou nitou vedúcou k vyššiemu vzdelaniu, $\mathrm{k}$,vznešeným ' umeniam, ktorých základ tvorí ,ars grammatica et musica ‘...] Ved' pravým hudobníkom je iba ten, pre ktorého hudba neznamená len každodenný ,usus, ale ktorý ju ovláda aj svojím duchom" ${ }^{8}$ Kompendiá tohto druhu zvyčajne traktujú podstatu hudby, jej význam a blahodarné pôsobenie na dušu, až potom prinášajú vlastnú teóriu. Z Levočského traktátu sa však zachovala iba čast’ s názvom Capitulum de modis musicae (kapitola o hudobných intervaloch), ktorá mohla byt aj názvom celého traktátu.

5 Pri skúmanej časovej perióde v rozmedzí 15.-18. storočia ide o predovšetkým o práce Z. Czagányovej, F. Matúša, J. Petoczövej, S. Kopčákovej, pozri bližšie čast̉ Literatúra.

6 Z. Czagányová, Anonymi Leutsoviensis Tractatus de musica, Slovenská hudba, roč. 17, 1991, č. 4, s. 297-327. Autorka prináša rozsiahly opis, analýzu a kritickú edíciu fragmentu s názvom Anonymi Leutsoviensis Tractatus de musica. Kópia rukopisu sa jej dostala do rúk v roku 1988. Súčastou jej štúdie je aj kritická edícia (prepis textu fragmentu), ktorý by bol vo forme faximile velmi tažko čitatelný.

7 Tamtiež, s. 297, autorka uvádza, že prvé zmienky o „fragmente traktátu“ sa u nás vyskytli v r. 1982, upozornil na ne historik J. Sopko, v r. 1988 sa jej dostala do rúk kópia rukopisu, ktorý sa na našom území už nevyskytuje. V r. 1780 ho (spolu s dalšími vzácnymi rukopismi a kódexmi) po dohode s mestskou radou v Levoči odkúpil sedmohradský biskup Ignác Batthyány a previezol ho do mesta Alba Iulia. Tam leží rukopis v známej knižnici Batthyáneum dodnes. Miestom vzniku fragmentu je podla hypotézy muzikologičky Czagányovej Levoča.

8 Tamtiež, s. 303. 
Z hladiska hladania stôp dobovej reflexe estetického pôsobenia hudby na človeka je však vhodnou bázou $\mathrm{k}$ niekolkým poznámkam. Východiskovými tézami sú v nej dve klúčové definície hudby: Boethiova ${ }^{9}$ a Izidorova. ${ }^{10}$ Levočský autor používa názov „modus“, ktorý sa v skorších traktátoch používal vo význame stupníc ako radov tónov, zoskupených na základe antickej hudobnej teórie z dvoch tetrachordov, až od 12. storočia sa objavuje v zmysle interval. ${ }^{11}$ Levočský neznámy autor (vysoko pravdepodobne študent-kopista opisujúci text prednášajúceho učitela daný pre potreby výučby vopred $k$ dispozícii) uvádza 13 intervalov. K ich analýze pristupuje vektorom od definície zodpovedajúcej spoločenskej mienke vtedajších teoretikov $\mathrm{k}$ stručnému, ale precíznemu a jednoznačnému „estetickému exkurzu“ o zvukových kvalitách intervalu. Potom pristupuje k štrukturálnej analýze ich stavby, s čím súvisí aj etymologický výklad názvov modov (hladanie pôvodu slov v ich znení), čo patrilo $\mathrm{k}$ frekventovaným metódam stredovekej hudobnoteoretickej literatúry. Práve tento článok uvažovania však bol z dnešného hladiska naivný, pretože preberal zle interpretované názory antických myslitelov spojené s nejasným mytologickými predstavami o pôvode vecí. Z. Czagányová charakterizuje autorovo uvažovanie nasledujúco: „Podla toho, ktorý modus uznával za vhodný a nerušivý, resp. za nevhodný, dráždivý, možno v jeho systematike zretelne odlišit tri skupiny“: ${ }^{12}$

1. Mody, ktoré pre svoju „nedokonalú“ stavbu neznejú dobre.

2. Mody „živé, silné, odvážne, plne a dokonale znejúce“. Zaujímavostou je, že autor tu zaraduje aj tritonus, predtým považovaný za „diabolus in musica“ (diabolský interval zväčšenej kvarty), ktorý sa síce menej používa, ale pôsobí velmi zaujímavo a ozvláštňujúco.

3. Tu patria tri stabilné „čisté" konsonancie (kvarta, kvinta a oktáva). Ich privilegované postavenie má pôvod $\mathrm{v}$ ich klúčovej pozícii $\mathrm{v}$ tónovom systéme antických matematikov. $^{13}$

Levočský hudobnoteoretický traktát (ktorého miesto a čas vzniku, podobne i predlohy, ktorými bol inšpirovaný či ktoré kompiluje, a sú určené zatial iba hypoteticky, resp. pravdepodobnostne na základe komparácií s podobnými prameňmi) je jedným z najvzácnejších a najzriedkavejších dokumentov našej stredovekej kultúrnej histórie. Czagányová konštatuje, že si ho musíme vážit "nielen ako pamiatku hudobnoteoretického a hudobnofilozofického myslenia, ale predovšetkým ako dôkaz pružného, kontaktibilného začlenenia našej krajiny do celoeurópskeho kultúrneho kontextu". ${ }^{14}$ Je pravdepodobné, že podobných ešte neobjavených traktátov sa vyskytuje na území Slovenska viac. ${ }^{15}$

9 Anicius Manlius Torquatus Severinus Boëthius (asi 480-525) bol rímsky senátor a filozof raného stredoveku, autor spisu De institutione musica, pozostávajúceho z 5 kníh ako základu stredovekej špekulatívnej teórie. Boethius sprostredkoval stredoveku tradíciu antickej hudobnej teórie.

10 Sv. Isiodorus z Sevilly (540-636), arcibiskup, pokladaný za posledného z učitelov „staroveku“.

11 Interval je v hudobnej teórii definovaný ako vzdialenost dvoch tónov, zvyčajne od nižšieho k vyššiemu.

12 Z. Czagányová, Anonymi Leutsoviensis Tractatus de musica, pozri hore, s. 306.

13 Napr. Ptolemaios, Phytagoras a další, pričom ich systém ako prvý sprostredkoval, zhrnul a interpretoval v 5. storočí teoretik Boethius.

14 Z. Czagányová, Anonymi Leutsoviensis Tractatus de musica, pozri hore, s. 316.

15 Ak by sa v budúcnosti našli dalšie podobné traktáty, vzhladom na ich potenciálne blízke datovanie predpokladáme, že by sme $v$ nich pravdepodobne narazili na tie isté (nanajvýš do istej miery varírované) poznatky a ich interpretácie, kedže ich pisatelia väčšinou kompilovali alebo tvorivo prerozprávali dobové teoretické príručky najvýznamnejších európskych teoretikov, s ktorými sa oboznámili ako absolventi univerzít v Čechách, Nemecku alebo Polsku. 
Podobným spôsobom fungovalo odovzdávanie poznatkovej bázy v období počiatkov reformačného humanizmu v druhej polovici 16. storočia. Väčšina vzdelancov pôsobiacich na Slovensku, presnejšie v slobodných královských mestách (napr. Levoča, Kežmarok, Bardejov), navštevovala univerzity v Nemecku, predovšetkým vo Wittenbergu. Mnohí vzdelanci tej doby pôsobiaci na Slovensku boli dokonca priamo študentmi či aj oblúbencami Filipa Melanchtona, najvýznamnejšieho spolupracovníka Martina Luthera. Toto tvrdenie platí v plnej miere v prípade bardejovského učenca Leonarda Stöckela, ktorý dostal už vo svojej dobe prívlastok „Praeceptor Hungaricae“.

\section{Hudobná teória a prvé výhonky estetického myslenia v rámci jej diskurzu v 16. storočí}

Vzhladom na začínajúcu protestantskú tradíciu školstva a filozofického myslenia v období po uskutočnení Lutherovej reformácie nachádzame na území východného Slovenska vzácny hudobnoteoretický spis Leonarda Stöckela De musica [I.] a De Musica [II.]. V nasledujúcich úvahách našou snahou bude na základe skúmania autorovho života a aktivít na poli teoretického a praktického vyučovania hudby vyabstrahovat’ a odcitovat z jeho traktátov tie myšlienky, v ktorých nachádzame zárodky estetického uvažovania, spojeného s výkladom hudobnoteoretických javov, prípadne ich traktovanie paralelne s výkladom ich estetickej pôsobnosti a na báze etického zhodnotenia vplyvu na život človeka na prahu novoveku.

Leonard Stöckel (1510-1560) patril v prvej polovici 16. storočia medzi najvýznamnejších sprostredkovatelov reformačných ideí na území dnešného severovýchodného Slovenska. Zásluhy tohto teoretika, reformačného humanistu a pedagóga na rozvoji hudobného života Bardejova vyzdvihol v slovenskej hudobnej historiografii v 80. rokoch 20. storočia Richard Rybarič, ktorý sa vo svojich syntetických akademických dejinách ako prvý zmienil aj o slávnej humanistickej škole v Bardejove, na čele ktorej bol „učený odchovanec wittenberskej univerzity Leonard Stöckel, zanietený milovník hudobného umenia“" ${ }^{16}$ Nové, konkrétne poznatky k Stöckelovej pedagogickej činnosti v Bardejove sa podarilo priniest’ v druhej polovici 80. rokov Františkovi Matúšovi. ${ }^{17}$ Samotné pedagogické aktivity na poli vyučovania hudby, hudobnej teórie a ešte menej známa matematicko-pedagogická činnost' Leonarda Stöckela však doteraz nebola predmetom vedeckého bádania. ${ }^{18}$

16 R. Rybarič, Dejiny hudobnej kultúry na Slovensku I. Stredovek, renesancia, barok, OPUS, Bratislava 1984, s. 73.

17 F. Matúšs, De Musica Leonardi Stöckelii, Slovenská hudba, roč. 17, 1991, č. 4, s. 360-416. Východoslovenský muzikológ František Matúš v 80. rokoch 20. storočia objavil v Lyceálnej knižnici v Kežmarku unikátny konvolút, obsahujúci okrem iných vzácnych rukopisov a dobových tlačí v príväzku aj dve rukopisné Stöckelove učebnice hudby De Musica [I.] a De Musica [II.] a jednu učebnicu matematiky, označenú ako Arithmetica Leonarthi Stöckelii.

18 Stöckelove spisy týkajúce sa hudby a matematiky sú objavom prešovského hudobného historika Františka Matúša. Pozri bližšie: F. Matúšs, De Musica Leonardi Stöckelii, Habilitačná práca, FF UK, Bratislava 1992. Táto práca vznikla už v roku 1989, ked’bola zadaná redakcii časopisu Musicologica slovaca na Ústave hudobnej vedy SAV, až o 3 roky neskôr bola predstavená ako habilitačná práca. Prvenstvo z hladiska skúmania spisu Arithmetica patrí práci S. Kopčákovej, pozri bližšie: S. Kopčáková, Leonard Stöckel a matematika, in: P. Kónya (ed.), Leonard Stöckel a reformácia v strednej Európe. Acta Colegii Evangelici Prešoviensis XI, Vyd. PU, Prešov 2011, s. 85-94. Kritická edícia tohto prameňa, napriek existujúcemu prekladu $\mathrm{z}$ latinského jazyka, dodnes nebola finalizovaná. 
Ranonovoveké hudobnoteoretické traktáty ${ }^{19} \mathrm{z}$ druhej polovice 16. storočia, resp. dvojdielny spis De Musica je nielen prvou učebnicou hudby nájdenou na našom území, ale aj cenným zdrojom informácií k dejinám hudobnej estetiky, kritiky a filozofie hudby. Jeho stránky sú pretkané filozofickými, etickými a estetickými úvahami. Predstavujú unikátny Stöckelov pohlad na súdobé chápanie hudby ako umeleckej a teologickej entity disponujúcej aj etickou silou formovat ludskú osobnost: „, [...] hudobné umenie si treba najvyššie cenit', pretože je mimoriadnym Božím darom, ale aj vel'kou ozdobou cirkvi (magnum Ecclesiae ornamentum), dokonca aj vo večnom živote. Okrem toho slúži disciplíne. Má totiž osobitnú silu miernit ducha (ad animos mitigandos), robí ludí a nemé tváre krotkejšími“"20

$\mathrm{V}$ čase reformácie a rozvoja myšlienok humanizmu hudba dosiahla vysoké spoločenské postavenie. Na dôležité miesto sa dostala aj vd’aka profesionálnemu hudobnému vzdelaniu Martina Luthera (1483-1546), ktorý sa vel'mi usiloval o začlenenie hudby do sféry cirkevného i svetského života ako propagátor myšlienky spojenia teológie a hudby. V Lutherovom spise Ensomium musices (Chváloreč hudby) je hned’v úvode napísané: „Niet pochýb o tom, že mnohé semená dobrých cností vlastnia tí ludia, ktorí sa venujú hudbe. Tí ludia, na ktorých hudba nepôsobí, sú podobní pňom a kameňom. Vieme, že diabli hudbu nenávidia a neznášajú. A verejne oznamujem, a neobávam sa to vyhlásit, že po teológii niet takého umenia, ktoré by sa mohlo vyrovnat hudbe. Po teológii iba hudba poskytuje to, čo na inom mieste iba teológia môže poskytnút, a to duchovnú radost’ a spokojnoste. “21

Janka Petöczová vo svojej analýze traktátov v kežmarskom konvolúte ${ }^{22}$ charakterizuje ich hudobnopedagogické zacielenie: „Ide o stručne a prehladne koncipované kompendiá hudby, určené žiakom mestskej latinskej školy. Majú typickú výkladovú štruktúru: na začiatku je vyslovenie určitej otázky, pokračuje sa výkladom problematiky a dodržiavajú sa pedagogické zásady zrozumitelnosti a postupnosti učiva. “23 Prvé kompendium obsahuje elementárne hudobno-teoretické poznatky pre mladších žiakov, druhé je určené na prehl'bené a rozšírené štúdium chorálnej a menzurálnej hudby na vyššom stupni náročnosti, pre starších žiakov mestských latinských škôl. Obsahuje viac teoretických otázok a rozšírenú definíciu hudby. Leonard Stöckel bol dobre oboznámený s dobovými hudobnoteoretických príručikami 16. storočia. Pri koncipovaní svojich učebníc De Musica sa aj opieral o aktuálne trendy v uvažovaní o hudbe, predovšetkým o najznámejších nemeckých protestantských teoretikov Nicolasa Listenia a Heinricha Fabera. S Listeniom sa Stöckel dokonca aj poznal v priebehu ich štúdia vo Wittenbergu. Dôležitým sa teda ukazuje fakt,

19 Rukopisné traktáty Leonarda Stöckela sa nachádzajú v Lyceálnej knižnici v Kežmarku (konvolút sign. N 139, st. sign. S 38956). Tie texty o hudbe, ktoré majú datovanie, pochádzajú z rozpätia rokov $1566-1578$.

20 De musica [I.], Quid este musica? Odsek Quid hinc sequitur? Citované podla F. Matúš, De Musica Leonardi Stöckelii, pozri hore, s. 394.

${ }^{21}$ De musica [I.], Quid este musica? Odsek Quid hinc sequitur? Citované podla: tamtiež, s. 368.

22 Matúš vo svojej habilitačnej práci uvádza, že základnou jednotkou konvolútu je učebnica matematiky Gamma Frisia, dve tlačené učebnice hudby Nicolausa Listenia (1510-?), nemeckého hudobného teoretika a Heinricha Fabera (1500-1552), nemeckého hudobného teoretika, skladatela a kantora F. Matúš, De Musica Leonardi Stöckelii, pozri hore, s. 105). Na s. 99 autor upresňuje, že kežmarský konvolút obsahuje celkovo až štyri Stöckelove hudobnoteoretické spisy. Okrem De Musica I. a II. aj dalšie dva krátke spisy, obhajujúce v zložitých dobách konštituovanie luteránskeho vierovyznania na Slovensku právo hudby na jej účast v cirkevných obradoch.

23 J. Petoczövá, Leonard Stöckel a hudba, in: P. Kónya (ed.), Leonard Stöckel a reformácia v strednej Európe. Acta Colegii Evangelici Prešoviensis XI, Vyd. PU, Prešov 2011, s. 75. 
že išlo o bezprostredný a prirodzený transfer bez obsahových deformácií. Historickú hodnotu traktátov hodnotí J. Petöczová slovami: „Ich vysoká výpovedná hodnota pre poznanie regionálnych dejín hudobnej výchovy i pre poznanie uhorských a európskych hudobnokultúrnych kontextov ich radí k najvýznamnejším muzikologickým prameňom dneška." ${ }^{24}$ My ešte zdôrazňujeme ich hodnotu z hladiska opísaných estetických účinkov hudby na človeka v nich, presahujúcich do pomenovania výchovnej funkcie hudby, teda v spojení s jej étosom.

\section{Estetické myslenie o hudbe na pôde prešovskej filozofickej školy v 17. storočí}

Konkrétnejšie kontúry tradície hudobnoestetického myslenia, zakotvenej v poznaní prác dobových teoretikov (ich spisov, filozofickej, estetickej či hudobnoteoretickej literatúry s prvkami estetického uvažovania) na príklade zvolenom na teritóriu východného Slovenska, môžeme dokumentovat’ v 17. storočí na pôde Prešovskej latinskej školy, predchodkyne v Uhorsku presláveného evanjelického kolégia. Ako prvý ju pertraktuje František Matúš v teoretickej štúdii „Prešovská filozofická škola a hudba“ (1984), ktorá je v slovenskej hudobno-historiografickej spisbe ojedinelou prácou svojho druhu.

Od polovice 17. storočia pôsobila na prešovskej latinskej mestskej reformačnej škole skupina pedagógov, ktorí svojou aktivitou na poli filozofického myslenia vstúpili do dejín filozofie na Slovensku pod názvom Prešovská evanjelická škola. Matúš zdôrazňuje, že doposial' neznáma je skutočnost', že niektorí z jej príslušníkov venovali vo svojich vedeckých dielach (v kontexte analýzy filozofického myslenia) pozornost' i problematike hudby a umenia, resp. hudobná realita v úzkom rámci ich filozofického myslenia mala svoj odraz i v širších súvislostiach činnosti školy. K najvýznamnejším osobnostiam patrili Ján Bayer, Izák Caban, Eliáš Ladiver ml., a d’alší. ${ }^{25}$ Miesto hudby v myšlienkových konšteláciách prešovskej evanjelickej školy je vyjadrením jej rastúceho významu v meniacej sa sociálnej štruktúre v období humanizmu a renesancie so silným vplyvom protestantského teologického racionalizmu. ${ }^{26}$

Ján Bayer (1630-1674), prešovský rodák, pôsobil v rokoch 1659-1666 ako profesor a neskôr ako rektor mestskej školy v Prešove. Jeho najpozoruhodnejším filozofickým spisom je práca Filium Labyrinthi vel Cynosura seu Lux Mentium Universalis ${ }^{27}$ (Košice 1663). V autorovej koncepcii práce Lux mentium (Svetlo myslenia) Bayer vymenúva vlastnosti duše, za ktoré považuje predovšetkým schopnost' poznávania za účasti fantázie, zmyslov, dokonca aj snov, neopomína však ani hnutia mysle (afectus), akými sú radost', zármutok, nádej. ${ }^{28} \mathrm{~V}$ spise sa síce hudba vyskytuje len ako sekundárny jav, nachádzame tu však pozoruhodné traktovanie hudobnoteoretických otázok. V spise vytvorenom

24 Tamtiež, s. 82.

25 So životom a dielom osobností prešovskej filozofickej školy sa možno bližšie oboznámit’ v prácach prešovských filozofov a historikov, my vychádzame z práce R. Dupkalu - P. Kónyu a z práce S. Felbera, pozri bližšie čast' Literatúra.

26 F. Matúš, Prešovská filozofická škola a hudba, Opus Musicum, roč. 16, 1984, č. 9, s. 271.

27 Honosné názvy filozofických diel v Bayerovej dobe, ako Filium Labyrinthi (Nit' bludiska) a Lux mentium (Svetlo myslenia), svedčia o tom, aký velký význam svojmu dielu prikladal.

28 S. Felber, Ján Bayer, slovenský baconista XVII. storočia, Vyd. SAV, Bratislava 1953, s. 102. 
počas prešovského pôsobenia horlivo propaguje aj učenie Jána Amosa Komenského, ktorého názory na podiel hudby v súdobých vyučovacích systémoch sú dobre známe. ${ }^{29}$ Novým prvkom je Bayerovo chápanie súvislostí hudby s ostatnými javmi duchovného a materiálneho života. Filozof $\mathrm{v}$ menovanom spise vyjadruje názor, že na osvojovanie hudby má právo každý jedinec. Ako prírodovedne zameraný bádatel Bayer hudbe ako časti matematiky prisudzuje schopnost poznávania materiálneho sveta: „Aritmetika podnítila vznik nového oboru, jenž se nazývá hudbou anebo harmonií; zkoumá znějící zvuk a rytmus. Zde se pojednává o rozmanitosti zvuku, starých a nových zpěvech, zkoumají se jejich definice, postuláty, axiomy. ${ }^{30}$

Bayer sa dokonca pokúsil o vylepšenie systematiky vied Francisa Bacona tým, že jeho vlastná systematika ${ }^{31}$ predstavujúca v prvej časti knihy (Gnostika) triedenie vied obsahuje až 90 druhov vied a umení. Bayer považuje umenie za „pomocníka ludskej fantázie“, ale v jeho ponímaní aj vedy človeku čiastočne umožňujú styk s nadprirodzeným svetom a tiež ulahčujú človeku život. S. Felber ${ }^{32}$ to hodnotí slovami: „Medzi d’alšie vedy, ktoré pomáhajú ludskému pokoleniu, ráta etiku, politiku, ekonómiu a medicínu, ale aj hudbu a tanec, ktoré volá artes voluptuariae (umenia rozkoše) a remeslá. “33 Bayer svoju systematiku pozoruhodne buduje na základe rešpektovania zmyslových skúseností. Považuje ich za súčast poznania, ktoré je trojakého druhu (skrze vedu, skrze mienku a skrze vieru), pričom v $\$ 3$ tvrdí, že „chciet nájst pravdu a vynechat’ smyslové počitky je nezmysel“ ${ }^{34} \mathrm{Na}$ tom istom mieste konštatuje, že jednotlivé správy zmyslov (pocity) „spája potom rozum (intellectus) na celkové obrazy (imagines, species intelligibiles)“. Zdôrazňuje, že skúsenost vznikajúca na základe zmyslových vnemov nesmie byt náhodná, primitívna (rustica), ale musí byt získavaná plánovito a s rozvahou (iudicosa), prednostne pokusmi, prípadne osvojovaním si cudzej skúsenosti. ${ }^{35} \mathrm{Z}$ praktického hladiska sa potrebné zmienit sa o jeho návrhu nového školského poriadku kolégia ${ }^{36}$, ktorý však nebol realizovaný, resp. magistrát ho neschválil. ${ }^{37}$

29 R. Dupakala, P. Kónya (eds.), Antológia z diel profesorov Prešovského evanjelického kolégia. I. Filozofia, FF PU, Prešov 1999, s. 51.

30 Citované podla: F. Matúš, Prešovská filozofická škola a hudba, pozri hore, s. 272.

31 Vlastná Bayerova systematika je rozpracovaná v kapitole $O$ prírodných a experimentálnych vedách, jej subkapitola Dejiny ludí a umení prináša zaujímavý fakt, že autor ešte pred sekciu Dejiny hudby radí Dejiny zvuku a sluchu, po nich históriu čuchu a vône.

32 Práca Stanislava Felbera Ján Bayer, slovenský baconista 17. storočia (1953) nie je kritickou edíciou dvoch spisov vytvorených počas pôsobenia v Prešove, Lux mentium (1663) a Ostium Naturae (1662). Obsahuje len parciálne preklady jednotlivých častí oboch spisov, súčasne je ich volným prerozprávaním a analýzou, obsahuje však cenné poznámky a indície vedúce k pramennej báze.

33 S. Felber, Ján Bayer, slovenský baconista XVII. storočia, pozri hore, s. 24.

${ }^{34}$ Citované podla: tamtiež, s. 28.

35 Podmienky pre správne zmyslové vnímanie stanovuje Bayer takto: 1. Poznávaná vec musí byt vnímatelná viacerými zmyslami. 2. Zmysly samé musia byt zdravé a schopné. 3. Pozorovanie musí byṫ vykonané v normálnom prostredí. 4. Pozorovat treba z primeranej vzdialenosti. 5. Treba riadne napnút pozornost' (attentio). Pozri bližšie: tamtiež, s. 28.

36 V roku 1662 sa Bayer stal rektorom prešovskej mestskej školy a začal usilovat o reorganizáciu prešovského lýcea. V r. 1667 bola slávnostne otvorená škola nazvaná Collegium Statuum evangelicorum seperioris Hungariae, pre ktorej potreby vypracoval návrh nového školského poriadku. Kedže sa však napokon jej rektorom nestal a navyše musel zbavený funkcie rektora opustit mesto Prešov (už v r. 1666), poriadok sa nerealizoval. Niektoré časti z neho však do praxe predsa len prešli, napr. školské a mimoškolské vyučovanie hudby v rámci vyučovania matematiky či stručné hudobnoteoretické informatórium.

37 Bayerov návrh vznikal v rokoch 1662-1666, po jeho odmietnutí magistrátom bolo dňa 18. 10. 1667 vzápätí otvorené prešovské kolégium hornouhorských evanjelických stavov. 
V. Ružička uvádza, že vo vztahu k mimoškolským aktivitám (piaty bod šk. poriadku) bola určená činnost’ alumnov, ktorí „obstarávajú hudbu a spev na nemeckom (v počte 20), mad’arskom a slovenskom (po 12 členov z prvej a druhej triedy) chóre a ich pomocníkov (adiutores alebo auditores). "38 Siedmy bod poriadku hovoril o školských slávnostiach (festa scholastica), ktoré sa štyri razy do roka realizujú „hymnami a deklamáciami“. 39 Z dejín hudobnej kultúry v Prešova máme poznatok, že na pôde Prešovského evanjelického kolégia takto prebiehala výučba (najmä cirkevného) spevu aj v nasledujúcich storočiach. ${ }^{40}$

Izák Caban (1632-1707), ako najbližší Bayerov spolupracovník, bol považovaný za najvýznamnejšieho atomistu v 17. storočí. Vo svojich filozofických traktátoch nedeklaruje hudobnú realitu v žiadnej priamej podobe, v duchu racionalistických tendencií sa zaoberá všeobecne pojmom krásy. K hudbe sa Caban dostal iba prostredníctvom mimoškolskej práce so študentmi pri nácviku študentských divadelných hier. Filozofické myslenie Eliáša Ladivera ml. (1633-1686), tretieho predstavitel’a prešovskej filozofickej školy, je dodnes málo preskúmané, $\mathrm{z}$ jeho tvorby sa zachovalo vel'mi málo. Z hladiska nedostatku prameňov je prakticky nemožné posúdit hudobne teoretickú realitu jeho filozofického učenia, v jeho prácach sú však vyjadrené jeho postoje k otázke funkcie hudby v školskej výchove. Jeho aktivity sa pozitívne odrazili v hudobnom živote Prešova, hlavne aktivizáciou študentov v rámci hudobných predstavení prešovského evanjelického kolégia. Ladiver pre ne napísal dve školské drámy. ${ }^{41} \mathrm{~V}$ druhej z nich, Udatný Papinianus (1669), sa na tú dobu výnimočne objavujú aj stručné režijné poznámky o charaktere scénickej hudby a spôsobe jej zapojenia do hry. ${ }^{42}$

Poznatky a pramenná báza k začiatkom hudobnoestetického myslenia na našom území sú a zrejme nadlho aj ostanú torzovité. Ani v jednom prípade nejde priamo o spisy, ktoré by v názve niesli podstatné meno „aesthetica“ či z neho odvodené adjektíva. Vo väčšine prípadov naše poznatky pochádzajú z literatúry pojednávajúcej o histórii filozofie, školstva či školských inštitúcií na Slovensku. Ďalším dôležitým zdrojom sú hudobnoteoretické traktáty, ktoré na určitých miestach svojich pojednaní sporadicky zachádzajú aj do oblasti pôsobenia hudby, mechanizmov jej vnímania cez dobovo nastavené teoretické postuláty ako aj mechanizmov jej účinkov zvažovaných dobovými teoretikmi v duchu paideia, teda pôsobenia na aktuálne vzdelávanú mladú generáciu, v tých časoch vychovávanú a vedenú najmä k práci, poslušnosti a chváleniu Boha cez vokálne a inštrumentálne činnosti.

V priebehu 18. a 19. storočia sa nám ako d’alšie zdroje pre odhalovane možných estetických náhladov ponúkajú príklady prác z hudobnoteoretickej alebo hudobnopedago-

38 V. Ružička, Školstvo na Slovensku v období neskorého feudalizmu, SPN, Bratislava 1974, s. 111. V rámci mimoškolských aktivít sa mali študenti cvičit v zborovom speve $\mathrm{v}$ zboroch podla národnosti (myslel tým 20-členný nemecký, 12-členný slovenský a 12-členný madarský spevácky zbor), aby zabezpečovali hudobné produkcie pri školských slávnostiach.

39 Tamtiež, s. 112.

40 Tento údaj preberá neskôr aj M. Potemrová, pozri bližšie: M. Potemrová, Kultúrne pomery v období feudalizmu. Hudobné pamiatky, in: I. Sedlák (ed.), Dejiny Prešova I, Východoslovenské vydavatel'stvo, Prešov 1965, s. 263. Autorka tu spresňuje, že tieto zbory mali pomáhat v kostole kantorovi, mali pestovat predovšetkým cirkevný spev, ale zrejme pestovali aj svetskú hudbu.

41 F. Matúšs, Prešovská filozofická škola a hudba, pozri hore, s. 274. Autor uvádza, že hra Eleasar Constans (1668) vyšla tlačou v Bardejove, Papinianus Tetragonos (1669) vyšla tlačou v Bardejove aj s uvedením mien hercov.

42 Tamtiež. 
gickej oblasti, rôzne zbierky nápevov, kde sa autor môže (no nemusí) pokúsit v krátkom teoretickom úvode k svojej práci vysvetlit’ podstatu hudobnoteoretického problému, prípadne ho vymedzit a esteticky zhodnotit. Určité záblesky estetického nazerania na povahu, tvorbu a pôsobenie hudby sa dokonca môžu objavit pri komparácii vývoja slovenského jazyka (resp. jeho súdobej podoby) s dobovým vývojom hudobnej kultúry a myslenia o hudbe na Slovensku. V etymologických, slovníkových a d’. prácach totiž určité terminologické snaženia zachádzajú aj do podoby opisov pôsobenia a účinkov hudby na človeka. ${ }^{43}$ Záverom nášho náčrtu zameraného na oblast’ východoslovenských stolíc môžeme konštatovat, že estetické vnímanie bežných ako aj umeleckých stránok nášho života nie je len doménou súčasnosti (v duchu túžby dnešného človeka mat veci nielen funkčné, ale aj pekné). Bolo prirodzenou súčastou vnímania životnej reality a jej poznávania rovnako u ludí v predchádzajúcich storočiach, aj ked' nám ich dôkaz ostáva často skrytý či implicitne vnorený do výsledkov ich umeleckých aktivít (nie vždy priamo hudobných ako skôr literárnych a dramatických), teoretických vedeckých aktivít ako aj pedagogických aktivít v kontextoch súdobej kultúry. ${ }^{44}$

\section{LITERATURA}

Bella, J. L., Myšlienky o vývine národnej hudby a slovenského spevu, Hudobnovedný zborník SAV, roč. 1, 1953, s. 20-48.

Bernolák, A., Slowár Slowenskí Češko-Latinsko-Ňemecko-Uherskí seu Lexicon Slavicum Bohemico-Latino-Germanico-Ungaricum, [Typis et Sumtibus Typogr. Reg. Univers. Hungaricae], [Budae] 1825.

Czagányová, Z., Anonymi Leutsoviensis Tractatus de musica, Slovenská hudba, roč. 17, 1991, č. 4, s. 297-327.

Dupkala, R., Prešovská škola. Filozofia na evanjelickom kolégiu v Prešove, FF PU, Prešov 1999.

Dupakala, R.; Kónya, P. (eds.), Antológia z diel profesorov Prešovského evanjelického kolégia. I. Filozofia, FF PU, Prešov 1999.

Felber, S., Ján Bayer, slovenský baconista XVII. storočia, Vyd. SAV, Bratislava 1953.

Kopčáková, S., Hudobnoestetické myslenie Jána Levoslava Bellu a jeho odozva po návrate na Slovensko, Kremnický letopis. Annale Creminiciensis, roč. 11, 2012, č. 2, s. 23-25.

---, Leonard Stöckel a matematika, in: Kónya, P. (ed.), Leonard Stöckel a reformácia v strednej Európe. Acta Colegii Evangelici Prešoviensis XI, Vyd. PU, Prešov 2011, s. 85-94.

---, Vývoj hudobnoestetického myslenia na Slovensku v 20. storočí, FF PU, Prešov 2013.

Lengová, J., Poznámky k úvahám J. L. Bellu o slovenskej a slovanskej hudbe, Ján Levoslav Bella v kontexte európskej hudobnej kultúry. Bibliotheca Musicae neosoliensis BMC. Zv. 1., Nadácia J. L. Bellu, Banská Bystrica 1993, s. 14-20.

Matúš, F., De Musica Leonardi Stöckelii, Slovenská hudba, roč. 17, 1991, č. 4, s. 360-416.

43 Velmi podnetné sú z tohto hladiska hudobno-terminologické snaženia slovenských osvietenských vzdelancov ako nepriamy, resp. sprostredkovaný odraz dobového chápania hudby a hudobnej kultúry. Napr. za takú možno považovat lexikografickú prácu Antona Bernoláka Slowár Slowenskí Česko-Latinsko-Ňemecko-Uherskí (pripravená do tlače r. 1796, vyšla však až po autorovej smrti v rokoch 1825-1827). Bernolák tam širšie sumarizuje aj slovenskú hudobnú terminológiu, navyše ju vysvetluje aj etymologicky. Vyjadruje sa k otázkam pôsobenia hudby (napr. „hudba tažkú mysel robí"), znenia a hlasu, hudbu radí k slobodným umeniam, uvádza termíny súvisiace s usporiadaním zvukovej štruktúry a d. Pozri bližšie Bernolák, A., Slowár Slowenskí Češko-Latinsko-Ňemecko-Uherskí seu Lexicon Slavicum Bohemico-Latino-Germanico-Ungaricum, [Typis et Sumtibus Typogr. Reg. Univers. Hungaricae], [Budae] 1825.

44 Táto štúdia je výstupom z projektu VEGA č. 1/0137/15 s názvom Hudobnoestetické myslenie na Slovensku. K problémom genézy, vývinu a kreovania v 19. a 20. storočí. 
---, De Musica Leonardi Stöckelii, Habilitačná práca, FF UK, Bratislava 1992.

---, Prešovská filozofická škola a hudba, Opus Musicum, roč. 16, 1984, č. 9, s. 270-274.

Petoczövá, J., Leonard Stöckel a hudba, in: Kónya, P. (ed.), Leonard Stöckel a reformácia v strednej Európe. Acta Colegii Evangelici Prešoviensis XI, Vyd. PU, Prešov 2011, s. 70-84.

Potemrová, M., Kultúrne pomery v období feudalizmu. Hudobné pamiatky, in: Sedlák, I. (ed.), Dejiny Prešova I, Východoslovenské vydavatel’stvo, Prešov 1965, s. 262-263.

Ružička, V., Školstvo na Slovensku v období neskorého feudalizmu, SPN, Bratislava 1974.

Rybarič, R., Dejiny hudobnej kultúry na Slovensku I. Stredovek, renesancia, barok, OPUS, Bratislava 1984.

Vajcik, P., Školstvo, študijné a školské poriadky na Slovensku v XVI. storočí, SAV, Bratislava 1955. 